\title{
Resistance Through Language Appropriation to Create a Reality for Oneself in the Postcolonial Nigeria
}

\author{
Magdelene H. Brown \\ School of Social Sciences and Languages, Vellore Institute of Technology, Chennai, India \\ Patchainayagi S. \\ School of Social Sciences and Languages, Vellore Institute of Technology, Chennai, India
}

\begin{abstract}
English Language to carry the native's experiences and the strategies deployed by the authors of Nigeria to reconstruct Africa's taunted imageries and cultures through their use of language. This article also examines the pattern that has been documented in Nigeria and re-evaluates some of the identified resistant strains that authors consciously or unconsciously integrate to ensure that their works are authentic. Author/Character/community or a nation is built through an indigenous choice of vocabularies that reflect the meanings of native society. Creative authors, especially with the postcolonial attitude, employ narrative strategies by using indigenous phrases and other signifiers to deviate from the standard variety to foreground the indigenized realities of the marginalized. Appropriations in the English Language help the colonized reconstruct their culture and history's lost and hidden truths. These strategies give the text an authentic identity representing the bare realities of the indigenous community. The indigenized medium of expression is also considered a form of resistance towards Eurocentric linguistic hegemony. The colonized writers articulate their native ideologies and beliefs without depending on the medium of a foreigner. The collection of criticisms in this paper will enable the upcoming writers to know and discover the elegance and inestimable elements in their native Nigerian literature than foreign literature with an alien culture that is hardly incomprehensive. The work also confirms the mimetic nature of Language and its interdependence with society.
\end{abstract}

Index Terms - Nigerian prose, resistance, reality, reconstruction

\section{INTRODUCTION}

Time and again, Language is being debated among the postcolonial realm of authors and critics for its lack of Eurocentric features. Colonizers actively and subconsciously promoted the English Language's superiority over all other native languages, even to the point of forbidding indigenous from speaking in their mother tongue. There were even records of humiliation while imperializing the English Language among the colonies. In response to oppressiveness through the Imperial Language, the critics and few activists retort to such practices by appropriating the Standard English language or a Eurocentric language to suit native consciousness and aura. While a few choose to appropriate, another bunch of writers completely abandon the imperial or global Language and return to the native language in all communication mediums. Ashcroft et al., a critic and theorist, comes up with a concept of Appropriation through Abrogation to deliver the native experiences against the Eurocentric norms. Appropriating the standard variety rested power in the hands of the native writers who were desperate to resist and rewrite their taunted history. The natives were broadly branched into two types, the physical and the rhetorical power. Physical power can only be exerted or implemented on an underprivileged or subordinate group. On the other hand, rhetorical power causes a person's consciousness to be disrupted, and their self-confidence weakens. The native linguaphiles attempted to oppose and overcome this rhetorical strength to give their art an authentic touch. Words are more powerful than weapons. When 'words' are mentioned, one has to look into its roots to discuss 'language' as it is the Language that gives an individual the power over the others in the society. To exert control over the other, Language is an inevitable tool in the hands of the ones in authority as it captures the breadth of human thought and endeavor.

\section{REVIEW OF LITERATURE}

Language is often considered a signifying system at the rudimentary level in its analysis but when streamed into the interest of its signification, do we realize the politics and power behind its usage. Max Weber (2007), a German sociologist, defines power as the " ability to control others, events, or resources; to make that happen what one wants to happen despite obstacles, resistance, or opposition." An English novelist, Angela Carter (2000), quotes that "Language is power, life and the instrument of culture, the instrument of domination and liberation." The language was a tool in the 
oppressor's hands to dominate the other, and vice versa. The oppressed had to use the same tool to liberate themselves from the clutches. "We tend to look through the language and not realize how much power it has, "says an American academician and a linguistic professor, Deborah Tannen. The rising postcolonial criticisms attempt to offer their ideas to the nation to empower the writers and readers to claim this authority. The empowerment is done through the Language used to frame themselves and the society around them. The act of resistance through Language that existed in the realm of the postcolonial paradigm is the core of the review paper.

David Crystal (2008), in his Cambridge Encyclopedia of Language, records the seven functions of languages, to express emotions, document the facts, instrument the thoughts, describe identity, interact with the society, the power of sounds, and define identity control the reality. One of the most potent purposes of language is to shape reality, which will be examined in detail with reviews from various critics and authors. A language lets a person see the past only to the extent it would allow him to see. The construction of reality is limited and draws boundaries with Language. The philosophy of Friedrich Nietzche on Language is how it influences how we perceive the world and what it makes us think and do. He also puts forth a fundamental question concerning everyman's relation to truth. Neitzche also confines the two critical functions of language "the means by which we construct the world " and "the tools by which [we] must deal with the world "(Deleuze \& Tomlinson, 2006). He further proceeds to say that, as we use the language to explain reality, the reality is already assumed by that person the 'words' become the "sound form of the concepts. we are only a species of "clever animals [which] invented cognition," deceived by our invention; there is no single truth, no concepts independent of Language, no one reality outside of us that causes our cognitive activity" (Deleuze \& Tomlinson, 2006). He affirms that there is no particular reality as we have several languages recording according to their adaptability. Kantian philosophy talks about the relationship between experience and reality; he says reality does not bounce beyond the experience but within. As Language shapes the thoughts about reality, the reality is assumed or presupposed. In that case, our knowledge about reality is determined through Language. The reality that we perceive it to be is that Language provides. So if one has to get access to "reality", they have to go beyond the realm of language and culture.

As the conferring is about, Language is a tool in constructing the reality; it would be precise to quote Ferdinand de Saussure (1998) "language becomes a mediator in accessing reality" (Saussure \& Harris, 1998) as he says there is no direct relationship between sign and reality in his Course in General linguistics.

George Orwell (1946) in his Politics and English Language mentions the phrase "doublespeak" as to how "Political language . . . is designed to make lies sound truthful and murder respectable, and to give an appearance of solidity to pure wind" (Orwell, 1946) also in his Novel 1984 he talks about a fictional language in his Novel, called the Newspeak, created by the authorities to control the cognitive capacity of the nation so that the ones in charge can exercise the ultimate power.

Culture and the Real, a book by the devotee of Lucan (2004), says that a child gets access to the real through a symbolic order. In contrast, the reality is beyond the symbolic order, and she also says that till the 19th century, it was believed that "culture was anonymous with the real" (Belsey, 2004). Later in the 20th century, through many schools of thought, a contradicting concept said that culture dictates the real and is not anonymous. The 20th-century theories have further moved on to construct reality or condition it through the languages used through any available media and books. More importantly, a language gets a pejorative meaning when used to represent the other.

Frantz Fanon (2008), in his Black Skin White Mask, narrates an incident inside the train where he was made to feel like an 'object' by a kid inside the train. The kid called him a Negro and kept on saying that he was being frightened at the sight of him. Fanons had to relocate his seat thrice in that train to avoid upheaval. The very few words that the kid in the train uttered constructed a negative image of reality around him, which had crushed his actual identity and made him isolate himself from the crowd. Fanon also says that he feels disintegrated inside by internalizing the colonizer's Language.

Gauri Viswanathan (2014), in her book Mask of Conquest, validates the mirror-like function of the literary text to the Englishmen and how those texts became a mask to the exploitation that camouflaged the activities of the colonizers, the British rule in India. The mask here denotes the English Language introduced under 'English Studies' in the educational institutions. In his Minutes on Education, Sir Macaulay (1835) mentions a derogative comment on the Indian languages as he finds neither scientific nor literary information. The Language of the natives is poor and rude, and any translations to the native languages will be of no effect. He also puts forth a debate in the meeting between the English Language contrary to the Sanskrit or Arabic Language as to which one is 'worth knowing'. To substantiate his argument, Macaulay says,

I have never found one among them who could deny that a single shelf of a good European library was worth the whole native literature of India and Arabia. The intrinsic superiority of the Western literature is indeed fully admitted by those members of the committee who support the oriental plan of education

(Laurie \& Macaula, 2017)

The two eminent contemporary authors of the African nation, Ngugi Wa Thiongo and Chinua Achebe contradict writing literature ideologies. Ngugi says that the reason for various Kenyan indigenous languages to wither way was the invasion of English as the medium of education. He believes that African literature written in English does little justice to reality. African literature is oral primarily in tradition. When a non-native writer tries to record the oral into a written form, he misses out on the minute intricacies of their reality. He relies on the fact that Language carries the culture. To 
deliver his native culture in a non-native language is a hopeless way of expressing or exposing the reality of his nation to the world. Thiongo retires from writing in the English Language after a press meet where all the authors of African literature were invited except those who wrote the African literature in African languages. This incident affects him more that he retires from composing in the colonizer's language and begins writing them in Gikuyu and other indigenous languages. Ngugi argues that writing in African languages is the only way to resist the linguistic imperialism of English language. Chinua Achebe, on the contrary, uses the English Language as a 'tool' to write back to the colonizers by incorporating native folklore elements like proverbs, riddles, stories, myths and vocabularies to create a new English variety that suits his consciousness.

Achebe (2004) was always against the European notion, Art for art sake; instead, he believes in "art for heart sake" (Emenyonu \& Uko, 2004). Achebe, in a conversation with James Baldwin (1968), says, "Art has a social purpose [and] Art belongs to the people. It's not something hanging out there that has no connection with man's needs. And Art is unashamedly, unembarrassingly; if there is such a word, social. It is political, economic, and his art reflects his life. The whole life of man is reflected in his art" (Standley \& Pratt, 1989). The whole contemporary authors of African literature always debated on the medium of language used to describe their reality. It was also argued that a non-native write can never represent but only represent the realities of culture. Until the lions have their history, the hunters would boast and glorify their hunt says, Achebe.

H.K Bhabha (2004), through his translational studies, comes up with the word 'Hybridity' where he says that the process of Hybridization creates a 'third space', creating a new reality through a hybrid language.

Most postcolonial writers and critiques have always questioned language and the expression of reality. Would a nonnative language bear the burden of native culture has become a prompting question to many? Denial of a traditional medium, the English Language has become an unsuccessful attempt in many aspects as it has reduced the audience or the readers. There are several languages and dialects available to write in their respective languages, which would bring in a lot more issues in the writer's society.

To know if the non-native writers of particular literature do justice to the character portrayal, cultural representation, and other characteristics of that specific literature is what matters to the native writers who are passionate about enriching their literature. There are no exact translations of the indigenous words in the English Language, the narrative style, the patterns along with its intricacies vary in the colonizers' language, the sign and signified is not the same in different cultures, and languages are the unfulfilled demands of the writers who feel Language a barrier in expressing their reality. A part of the nationalist writers often find the European representation of the east to be an unsafe place to dwell, and the people are of a low calibre compared with that of the west. The reality constructed by the colonizers is always felt to be a distorted one so that they remain inferior objects like beings to the west or the colonizers.

The internalization of western ideologies and practices has fragmented the minds of the marginalized as they are under constant pressure to live on par with them. The standards or criterions created by them have broken the confidence and imperial spirit within the colonized as they relentlessly indulge in mimicking the westerners, not knowing that they can never become like them and are unique in their ways. To domesticate the imported tongue is what a few tried to do, appropriating the Language to carry the burden of the indigenous language and culture to bridge the gap between the two. Pramod K. Nayar (2010) says

In each case, the postcolonial writer asserts her identity, not in an abandonment of the former European master's Language, but its appropriation. A postcolonial identity is forged, in many cases, not in return to a pre-colonial language or a 'pure' form, but in hybridization where political independence means that the postcolonial is empowered through the colonial past to fashion a new identity. While it is possible to argue $t$ this makes postcolonialism a derivative discourse and form; it is also clear that a Hybridization is an act of agency and freedom where the writer creatively uses English... to show how the crucial weapon of colonization can become a weapon of the postcolonial as well. (Nayar, 2010)

Colonial Language and Postcolonial Linguistic Hybridity, a dissertation by Jarica Linn Watts (2011), write commendably about how the Language plays a role in shaping the Reality of the Africans; she poses four research questions such as: "(1) how the texts use language to either include or exclude others; (2) how the characters interpret and respond to the mix of original and new languages; (3) how language usage either deters from or solidifies the sense of belonging together on the part of colonial natives; and (4) how language functions as a force in each text considered." (Colonial Language and Postcolonial Linguistic Hybridity| Theses \& Dissertations, 2011) The conclusion she gives for the questions above is that Language or the linguistic aspect of the Language has more to do with the social part much as it has to do with words. As N.F Blake also says that the use of nonstandard varieties of the Language in literature is likely to remain an essential tool in the writer's kit, but how it is exploited remains to some extent outside his control, for it depends upon a broader attitude to Language in the society in which he lives. This quote of Blake brings in a question of, which comes first, the change in the community that is reflected in the Language or the difference in the Language that is reflected in the society. It can either be a mimetic expression in the novels or an intentional practice to resist the standard variety.

\section{ENGLISH LANGUAGE AND NIGERIAN ENGLISH}


Historians and critics coarsely categorized the Nigerian's literature according to their age into four different periods; the first of the pioneers in the written literature of Africa and especially of the Nigerians is the 'fourteen kingdom period' stretching between the 10th to 18th century. The Muslim Arabs had won the conquest over the Africans. Then came the 'Sokoto period', predominantly significant between the 19th and 20th centuries. There are histories, poetry, Language and other documentaries written during that period. The early 20th century is the period of colonial literature. There were a lot of publications that emphasized the concept of imperialism and colonial alignments that dribbled into both literature and social power structures. The later parts of the 20th century and the current 21 st century are postindependence periods. There are strong traces of literary works unique to the African culture and traditions with a minimal affinity towards the western parameters. Only after the late 20th century did the written literature from Africa shrew the world by its native authors, whereas until then, they existed with their rich oral traditions. Once the written form came into existence, there was an intricacy between oral and written records of the literature. The evolution was not tranquil because the modern African literature was begotten by the education system levied by the westerns with parameters and models drawn from the European culture. Despite the imposition by the imperial cultures, oral tradition always had the edge over the other influencers.

Among the other countries in Asian, American and Australian continents, Nigeria stands more evident for their highest degree of exploitation among the colonized countries. The reverberation from this country, particularly from Africa, is enormous and concrete through its literature. The scars are more profound and strongly stained in Nigeria. It is easy for any foreigner to incorporate their Language into the African continent because it is made up of fifty-four countries with more than three thousand indigenous languages and dialects, and most of it was hieroglyphs, this made the English Language, with its generous capacity, grew imperial among the other indigenous languages. Exposure to other foreign languages resulted in a language shift at a sociolinguistic level in most prominent parts of the country. Language shift has its strata's starting from Diffusion, Induction, customization and finally native Recognition. English and French penetrated Nigeria through the ports of Badagry, where the Language diffused through trade and religion.

The continent was an amalgamation of the Arabs and Europeans after their conquest left Africans with multiple consciousnesses. They slowly started accepting French and English Language to be a medium to educate, govern and trade. Nicholas Lambert and Thomas Wyndham were the two European sailors who entered Nigeria for trading purposes. This process was quite demanding as the trading business led to formations of slaves under the sailors who came to trade; there were even traces of slave literature that sprung up during that period. Settlers claimed that Africans were not fully human since they couldn't compose poetry to legitimize their imperialism. Since the literary style and Language in the writing of African authors cannot be independent of their oppressed social experiences, the whites often regarded their establishments in all fields and especially in arts to be primitive and unpolished ones. The Negritude movement was initiated in Paris by the French-speaking African as they tried to express Africa and its oppression by the imperial culture of the French through the French Language in all forms of poetry, stories, plays and novels. The continuous attempt through this movement led to the black arts movement from 1930 to 1970 . Black arts movements in the year 1960s brought an end to language issues, and Africans regained their power over Language and other societal recognitions.

Meanwhile, the English missionaries in the 16th century came down to eradicate the slave trade and to set them free. Later on, the freedom from slavery was exchanged for spiritual bondage, which burdened the native's Use of Language. Victory over the French led to a subtle yet robust submission to the English. Mastering the Language like that of the westerns was not possible in the initial stages, so customization of English started among the speakers, especially among Nigeria's writers. Initially, underrated practices became a gratified expression style among Nigerian fictional authors as it witnessed enormous publications in Nigerian English. Although the glory towards a customized language remained intact for a few generations, the subsequent generations among the Nigerians mastered the English Language. They created their style without any mother tongue influences in writing while most of the themes contributed to its homeland. This final stage that the nation had reached is called native recognition.

The colonial period witnessed the ultimate power of the English over the other native tongues of the indigenous populations in Africa. During the period of colonization, oral literature was time-honoured and deep-rooted with its variety like the folklores, riddles, proverbs, epics and myths of People were made to believe that writing in languages of the west would add more value to their work of Art and that such results were always superior to the other world languages. The consciousness of the Africans was altered to write in the English language. The invaders' presence causes modifications in the locals' communication patterns.

French and English were two significant languages that were seen as the most considerable influence among the people of Africa, producing many bilingual and multilingual populations that suffered an identity crisis. In Africa, very few countries have their native tongue as their official language, and according to the thesis, even Nigeria holds English as its official language. The Nigerian literary writers can be broadly classified into three distinct generations of writers. The first generation of writers was manipulated to fascinate Western writing. Then the second generation was battling between indigenous national identity and global recognition. At the same time, the third or the current generation writers from the literary field have excelled in the exoglossic Language to create a perfect writing style for themselves adhering to the modern and competing literature of the other. 
African native languages did not flourish much in their literature, and a significant controversial disagreement broke out between the two groups of people having different opinions on the Language appropriate for their literature. During a conference in the year 1962, many argued that native languages would be more suitable for the literature, but at the same time, there was a group equally strong to oppose them. Obi Wali was the bigwig for the group that supported literature in native languages. They were called the 'pro-Africans'. On the other side, Chinua Achebe believed in appropriating the Language of the West to reach a broader range of audiences.

Literature in English does not carry the eminence found in English literature, was the approach of a group of people trying to be pro-Africa. Dathome, in African literature in the Twentieth Century, says that,

Literature in the written vernacular languages of Africa provides an imaginative and essential link with unwritten indigenous literature; this literature indicates the adaptability of oral tradition in that through the written vernacular literature, the oral tradition expresses its versatility and diversity. (Dathome, 1974)

Dathome further moves on to say that the oral traditions of the African culture can be preserved only through the means of writing them down in its vernacular tongue so that the elements of the oral traditions like the riddles, folklore, songs, proverbs and imageries would exist in the future without fading in the shadow of English language. Obi wali also talks about the importance of preserving indigenous languages through literature.

Amos Tutuola, a pioneer among the first group of African writers, was a fan of western culture and modern productions while opposing colonization in all its forms. His works were steeped in oral traditions, and his writing style was similar to that of a storyteller. The overall decolonization process, which spawned an anti-colonial movement, marked the second generation of writers. However, they were startled by the circumstances they found themselves in after independence, and writers from this period, like Chinua Achebe, Ngugi Wa Thiongo, Buchi Emecheta, Ama Ata Aidoo, and others, focused their work primarily on the predicament of their nations after freedom. These works attempted to adapt European languages to the African context and appropriate the standard variety by the native tongues. The third-generation writers were almost like the second but had a refined style and theme that awakened the world to their writings. Chigozie Obioma, Mariama Ba and Chimamanda Ngozi Adichie are contemporary or third-generation writers. The novels that are chosen for the study are Palm wine Drinkard by Amos Tutuola (1952), A Man of the People by Chinua Achebe (1966), Devil on the Cross by Ngugi wa Thiong'o (1980), Purple Hibiscus by Chimamanda Ngozi Adichie (2003), An Orchestra of Minorities by Chigozie Obioma (2019). The selection was based on novels published during colonization, post-colonization, and the recent modern era. The techniques carried out by each writer, consciously or unconsciously, to remain loyal to their indigenous cultural roots through Language will be examined in the study.

\section{DisCUSSION}

Culture blooms only when language rains. There are no indications of culture separate from Language or vice versa. A cultural framework outlines the language patterns that emerge when people meet in a specific setting at a particular time and location. The combination and domination of the English Language made the postcolonial writers resist the control laid on their medium of expression. The bondages of linguistic limitations were broken through appropriation and abrogation.

Appropriations in the literary texts by the marginalized had been a creative tool in enhancing the native nub of any author who wanted to glaze his culture and identity with the reality that the natives experience. Bilingualism is innate in any postcolonial writer; to use that inherent particulate quality in establishing an identity or accepting the given identity by the west is what makes a difference. Appropriating strategies vary according to the authors' level of bilingualism or multilingualism; for example, Amos Tutuola and his novels are examples of literal bilingualism. The author's strategies reflect his lack of exposure to the English Language. Still, on the contrary, there are also authors like Achebe and who belong to the category of co-ordinate bilingualism, where the strategies spring out from expertise in both their native and English Language. Both writing styles are known for their inventiveness and originality, irrespective of their level of bilingualism. Indian and African literature contributes more to this realm of appropriated, profoundly recognized and appreciated literature. The authors reconstruct their broken identity through this artistic use of Language. It works in both affirmative ways by either becoming an act of resistance toward language hegemony or facilitating the authors in creating a new identity through language usage.

The spotted strategies among some postcolonial writers to indigenize a text in their style are (1) word coinage or borrowing in their text, (2) use of native similes and metaphors in targeted text, (3) translated proverbs and idioms and other folkloric elements from native to target text,(4)transfer of rhetorical devices from the native to the target text, (5) code-switching and code-mixing. Among the five, the use of native rhetorical devices plays a most crucial role in inclining towards the construction of indigenous literature. The rhetorical devices used are Euphemisms, Dysphemism, Loaded rhetorical Questions, Hyperbole, Understatement, Repetition and Images.

Euphemism is a lenient or mild phrase exchanged for a harsh one, usually used in narrating intimate scenes among characters, "As soon as her husband touches her, she gets a swollen tummy..." (Emecheta, 1983); here, the word swollen tummy is used instead of pregnancy is emphasized by Buchi Emecheta in her second class citizen novel, another example of Euphemism is from Thiong'o's (2007) Wizard of the crow where he calls the 'school girls' as 'spring chicken' (Thiong'O, 2007). Words are replaced to display politeness in the background. Dysphemism is the opposite for 
Euphemism as it is used in creating humour or in offensive situations. "Your greatest ruin is this woman who rules your heart and house" (Betiang, 2011) is a phrase from the novel Cradle on the scales (2011), here the woman is compared to destruction.

Loaded rhetorical questions are asked not expecting an answer but to either emphasize the content or character. In the novel Things Fall Apart, Chinua Achebe (1994) tries to emphasize the thoughts running in the mind of a boy who was self-talking as he was thinking about his family members "Would he recognize her now? She must have grown quite big how his mother would weep for joy and thank Okonkwo for looking after him so well and bringing him back [...]. Could he remember them all?" (Achebe, 1994).

Hyperbole is a tool used in exaggerating the given meaning. Adichie, in her novel Purple hibiscus (2012), exaggerates to describe a big house as "My son owns the house that can fit in every man in Aba" (Adichie, 2012). Repetition and images create a rhythm and colour for the readers, making the text more memorable and appealing.

Apart from the rhetoric discourse, the strategies mentioned above also play a vital role in appropriating the text to carry the burden of the natives. Loan words or coinage are seen in almost seventy per cent of Nigerian novels. Terms such as "Drinkard" for "drunkard", "juju" for "talisman", "doings" for "action" are accepted usage by given to the audience by Amos Tutuola (1939) in his Novel "The palm wine Drinkard" (Tutuola, 1993). Similes and Metaphors are the most found strategic tools in indigenous novels; Butchi (1983), in her second class citizen, uses similes and metaphors in high proportion to bring out the psychology and cognitive skills of the natives through her Novel, one such example for a simile is "Her mouth started to water like that of a starving dog, so she turned away" (Emecheta, 1983), the simile here denotes hunger, poverty of the character in the Novel.

Metaphors are there in abundance in the same Novel, "These women were so proud of this new lawyer because to them it meant the arrival of their very own Messiah." (Emecheta, 1983); here, the lawyer is compared to a Messiah.

Proverb and idiom translation is inherent among second-generation writers like Achebe and Thiong'o to portray the realities of the social life of the author or his characters in its space. "If the palm wine tapper is praised, he dilutes the palm-wine with water" (Tutuola, 1993) is a proverb that tells how a person loses his integrity when he is praised. Idioms are used in places where a brief description is projected instead of descriptive. Butchi (1983), in her Second class citizen, writes about the bride price, a practice in the African culture, while asking the character named Adah to study even after her father's death as it would "tide boy over" during her wedding. The phrase "tide boy over" is a brief description of the bride price practice and the cultural heritage that the Africans follow as a part of their life.

\section{CONCLUSION}

Appropriating the standard variety is a significant pattern among first and second-generation Africans, especially Nigerian writers like Chinua Achebe, Ngugi Wa Thiong'o, Ngozi Adichie, Sefi Atta Vonani Bila. Their works contribute to bringing the creative and exciting writing style to keep the readers engrossed in the text. Appropriating a foreign language for the purpose of representing Nigerian reality, on the other hand, is a mimetic means of expressing the society in which the writers reside. The English Language remains at a height despite appropriation processes and abrogation in the language system. The Language's flexibility and generous capacity are also noted as it remains the medium of expression in any adverse situations. The Language is mended to be available in different forms but has never been replaced by another.

\section{REFERENCES}

[1] Achebe, C. (1994). Things Fall Apart. Penguin Books.

[2] Angela Carter. (1983). 'Notes from the Front Line', in Writing and Gender, ed. Michele Wandor. London: Pandora.

[3] Belsey, C. (2004). Culture and the Real: Theorizing Cultural Criticism (New Accents) (1st ed.). Routledge.

[4] Betiang, L. (2011). The Cradle on the Scales. AuthorHouse.

[5] Crystal, D. (1997). The Cambridge Encyclopedia of Language (2nd ed.). Cambridge University Press.

[6] Dathome, O. R. (1974). African literature in the Twentieth Century, U. S. A.: Heinemann.

[7] Dei, S. G. J. (2007). Racists Beware: Uncovering Racial Politics in the Post Modern Society. Sense.(3),32.

[8] Deleuze, G., \& Tomlinson, H. (2006). Nietzsche and Philosophy (Continuum Impacts). Continuum.

[9] Emecheta, B. (1983). Second Class Citizen (Reprint ed.). George Braziller Inc.

[10] Emenyonu, E. N., \& Uko, I. (2004). INKA, the Artistic Purpose: Chinua Achebe and Theory of African Literature (Emerging Perspectives on Chinua Achebe, Vol. 2). Africa World Press.

[11] Fanon, F., \& Philcox, R. (2008). Black Skin, White Masks (Revised ed.). Grove Press.

[12] Laurie, W. F. B., \& Macaula, B. T. B. M. (2017). Sketches Of Some Distinguished Anglo-Indians: (second Series) Including Lord Macaulay's Great Minute On Education In India. Andesite Press.

[13] Nayar, P. K. (2010). Postcolonialism: A Guide for the Perplexed (Guides for the Perplexed) (Revised ed.). Continuum.

[14] Orwell, G. (1946). Politics and the English Language: By George Orwell. Sahara Publisher Books.print.

[15] R. W. (1983). Toward Cultural Independence in Africa: Some Illustrations from Nigeria and Ghana. African Studies Review, 26(3/4), 119. https://doi.org/10.2307/524165

[16] Saussure, F., \& Harris, R. (1998). Course in General Linguistics (Open Court Classics) (Reprint ed.). Open Court.

[17] Standley, F. R., \& Pratt, L. H. (1989). Conversations with James Baldwin (Literary Conversations Series) (First Edition). University Press of Mississippi. 
[18] Thiong'O, N. W. (2007). Wizard of the Crow (Reprint ed.). Anchor.

[19] Tutuola, A. (1993). The Palm-Wine Drinkard and My Life in the Bush of Ghosts. Grove Press.

[20] Viswanathan, G. (2014). Masks of Conquest: Literary Study and British Rule in India (Twenty-fifth Anniversary ed.). Columbia University Press.

[21] Viswanathan, G. (2014). Masks of Conquest: Literary Study and British Rule in India (Twenty-fifth Anniversary ed.). Columbia University Press.

[22] Weber, Max. (1978). Economy and Society: An Outline of Interpretive Sociology. Berkeley: University of California Press.

Magdelene Aneetee H. Brown is a PhD student at Vellore Institute of Technology in Chennai. She received her bachelor's and master's degree in English Language and Literature from Madras Christian College. Her research concerns broadly fall under the larger field of Sociolinguistics and Postcolonialism. Analyzing the discourse of postcolonial Nigerian novel to find the underlying cultural connotations is her major source of interest.

Patchainayagi S. works as an Assistant Professor at the Vellore Institute of Technology, Chennai, with more than ten years of experience teaching technical English and communication skills to engineer students. Her research interests also include Canadian literature and Feminism. 